\title{
THE EFFECTS OF OCCUPATIONAL HEALTH AND SAFETY RISK FACTORS ON JOB SATISFACTION IN HOTEL ENTERPRISES
}

\author{
Dr.Gonca KILIÇ, Düzce University, School of Tourism and Hotel Management, \\ kilicgonca@hotmail.com
}

Assist.Prof.Murat Selim SELVI, Düzce University, School of Tourism and Hotel Management, muratselimselvi@duzce.edu.tr; mselvi99@hotmail.com

\begin{abstract}
Occupational health and safety risk factors can have direct or indirect effects on levels of organizational commitment, job satisfaction, and the job productivity of workers in service companies as well as other types of industries. In this paper, the effects of physical, biological, chemical and socio-psychological risk factors, related to occupational safety and health, encountered in hotel enterprises on job satisfaction were investigated. Questionnaire survey was conducted as a data collection tool to determine the levels of job satisfaction and opinions of the workers related to occupational health and safety risk factors in five-star hotel enterprises. The questionnaire consists of three parts: (1) Questions to determine some characteristics of hotel company and hotel workers, (2) Levels of risk related to occupational health and safety in hotel business (3) Questions to point out the workers' level of job satisfaction. Part two and part three of questionnaire consist of five Likert-type questions. Job satisfaction was measured using the Minnesota Satisfaction Questionnaire (MSQ). Hotel workers were asked to complete a questionnaire-form developed were implemented in February 2009. The study population included 204 employees from eight five-star hotels in the İstanbul Region. Statements about workers' level of job satisfaction and levels of risk related to occupational health and safety in hotel enterprises were described by calculating the frequency and percentage distribution, the arithmetic mean and standard deviation. On the other hand, relationship between workers' level of job satisfaction and levels of risk related to occupational health and safety were determined by correlation and regression analysis. In addition, if participants' opinions on workers' job satisfaction and risks related to occupational health and safety show a statistically significant difference by demographic characteristics were analyzed by t-test and variance analysis. According to the analysis stated above it is
\end{abstract}


expected that as long as the risk level on the occupational health and security increase the satisfaction level of the employees will accordingly decrease.

Key words: Occupational health and safety risks, Job satisfaction, Hotel companies.

\section{INTRODUCTION}

There occur new risks in the developed countries in parallel with the enlargement of the service sector. The most prominent ones of these risks leading to the occupational illnesses are especially muscular and skeleton diseases (YIlmaz, 2009; 55). The existence of the risks threatening the employees' health in the offices leads to the occupational accidents and occupational diseases. It is well-known fact that occupational accidents and the occupational diseases in the scope of the occupational health and security bring about losses both for the tourism sector and for the economy of the country. In other words, the occupational accidents in the business cause a considerable cost of time and cash because it created job losses. The number of the occupational accidents and diseases in Turkey in service sector is lower than that of the industrial sector as well as the height of the psychosocial and ergonomic risks, working conditions, the structure of the labour force and increasing employment make this rapidly-growing sector a new center drawing attention of the studies for occupational health and safety (Öncü, 2008). However the decrease in the productivity of the employees and motivation might result in the decline of the job satisfaction and organizational commitment (Kozak, 2006;168). The importance of the labour force is more important for the hospitality businesses attached to the tourism sector in which the labour is highly intensive than the other sectors. It is unlikely for the server who has low job satisfaction level to serve in a satisfactory way to the customer in a sector in which the customer purchases the service and served by the server face with. It is a must for the servers to be satisfied with their jobs and offices to make sure that the customers accommodate and leave in a way highly satisfied (Akıncl, 2002; 2). This issue has neither necessarily been a research topic nor analyzed in hospitality and food and beverage industry in Turkey.

\section{OCCUPATIONAL HEALTH and SAFETY}

The systematic and scientific researches conducted in the offices in order to avoid the conditions stemming from several reasons and likely to have harm on health during the carrying out of the work is called occupational safety. In other words occupational safety is a series of the actions performed with a view to refrain the employees from the occupational accidents and diseases. Health, in general, is a larger term than the security. What is meant by occupational health might be not to be disposed of occupational diseases, to avoid from fatigue during working, to avoid anti-aging and to ensure a qualitative living level. In 
other words, it is aimed to make sure that the employees are healthy and completely well-being (Seymen and Gül, 2004;199).

It is seen that the occupational accidents and diseases have regularly reduced within the last 10 years in the developed countries however it has been constantly increasing in the developing countries such as Far East, South America and African countries. During the last decade occupational accidents and diseases have decreased $10 \%$ in England, 35\% in Germany and $21 \%$ in Japan. As it has consistently decreasing in the USA the ratio has reached $6 \%$. The frequency of serious occupational accidents in EU has decreased \% 17 and that of fatal occupational accidents has decreased $23 \%$ between the years of 1998-2003. On the contrary it has gone up \% 48 in Taiwan, \%12.5 in Thailand, $141 \%$ in Singapore, $25 \%$ in Tunisia, 23.3\% in Argentina, 38\% in Spain, 36\% in Estonia, $19.5 \%$ in Latvia, \% 12 in Iceland, $18 \%$ in Poland, and $14.5 \%$ in Chili (Eurostat, 2007; 111) during the last decade.

The intensively seen occupational accidents along with the accelerating industrialization after 1980 have been a fundamental problem of our country. According to the figures of 2006, 79.027 occupational accidents and 574 occupational diseases have occurred in Turkey. The figures only show the employees registered to the SSK (Social Insurance Association) but they don't cover the self-employed, public employees and unregistered employees. The number of the fatal cases has approximately increased $100 \%$ within last two years and it reached the number of 1601 and this is one of the biggest figures of last 18 years (SGK, 2007).

The country which has undergone the worst conditions in terms of the health and the security of the servers among the EU and candidate countries is Turkey. Therefore, the harmonization process to the legislation of the EU for the health and the safety of the servers has leaded to a number of adjustments. Along with the labour law no. 4857 and in addition to the headings mentioned in 1475 , it was entailed to have an on-site doctor, an expert on the health and safety of the servers and a health and safety unit for the businesses considered to be an industrial that employ more than 50 workers. Besides, it is stated in the law that the employees should be trained about the health and safety of the servers (YIlmaz, 2009; 61).

\section{THE RISKS ABOUT THE OCCUPATIONAL HEALTH AND SAFETY IN HOTEL ENTERPRISES}

According to the study conducted by the Hellenic Institute for Occupational Health and Safety to fix the risk factors at the five-star-hotels operating in Athens the employees stated that they might be badly affected by the noise, enlightment and a number of chemical factors (Dienstbühl et al., 2008; 62). The main elements which are likely to create occupational accidents and diseases may be categorized into four groups (Kozak, 2006; 168). 
Physical Factors: Temperature, humidity, vibration, noise, enlightment and radiation.

Chemical Factors: Solid, liquid or gas chemicals which are inflammable, explosive, dangerous and harmful.

Biological Factors: The diseases stemming from microbes.

Psychological Factors: Human relations and disharmonies.

The factors like temperature, humidity, vibration, noise and the enlightment might physically harm people (burning, skinning, and cutting themselves or freezing) especially in the departments of food and drink, kitchen, floor services or laundry in the hotel enterprises. The employees working in the food and beverage department and in the kitchen utilize machines with electrically driven and extremely sharp knives to chop hard fruit and vegetables, slice them or to mince meat. Another physical risk which might be encountered by one who works in this department is to burn or skin themselves. Additionally another risk factor that is likely to be encountered at the large-scale hotel enterprises is the case of an employee's being locked in the deep-freezer (www.isguvenligi.net, 2009).

The risks stemming from the chemical factors cover all kind of risks coming along with solid, liquid or gas chemicals which are inflammable, explosive and harmful. Uyan (2008) states that the solid, liquid or gas chemicals such as carbon monoxide (CO) which is utilized for several reasons, ammoniac and PVC (polyvinyl chloride) may cause a number of diseases and result in deaths. The housekeeping services are one of the departments at which the risks stemming from the chemical factors are one of the highest departments at the hotel enterprises.

Dermatologic, muscular and skeleton system, auditory disorders, infections, respiratory tract diseases, allergies, injuries, flexions and traumas are seen at the hotel and food and drink industries. According to the data of the year 2003 of the Eurostat the mostly seen occupational diseases in the employees working at the hotel or food and beverage enterprises in EU countries are respectively muscular and skeleton diseases (\%50) and dermatologic disorders (\%29) (Dienstbühl et al., 2008;18).

Carpal tunnel syndrome is seen in the employees working in the kitchen and especially those who serve ice cream. However, housekeeping services are one of the departments which have the highest risks in terms of the occupational health at the hotels. According to a research conducted by Bolat et al., (2001) it is the second risky department ranking after the kitchen at the thermal tourism enterprises. The same authors indicate that the employees bear five risk factors like bacterial, dermatologic and rheumatismal diseases, the other diseases stemming from the chemicals and the diseases dependent on the physical factors and the bacterial diseases risk group is very high. 
Doormen and bellboys working at the front office are likely to suffer from the spondilolizis, injuries on the back muscles, spraining of the wrists and stiff necks. When the large groups check in at the hotels, it leads to the muscular and skeleton diseases to carry rapidly the heavy suitcases (www.isguvenligi.net, 2009).

The employees have to challenge against the psychological stress and the new risks like the visual effects stemming from the utilization of the ergonomic or screened machines in addition to the traumatic injuries, respiratory system diseases or occupational disorders encountered by the servers (Fuentes ve Ehrenreich, 1994; 11). When the distribution considering the sorts of the disorders is analyzed in the Eurostat data, it is seen that muscular and skeleton diseases are the mostly seen disorders throughout the EU (\% 53,1). They are followed by the occupational psychological disorders like stress and depression (\% 18,2) (Eurostat, 2003; 9).

Those who work for the leading service sectors face with a lot of psycho-social risks due to the inadequacy of the balance between work and life, ambiguous and nonstandard working hours, lack of control, heavy work load and time pressure increasing the stress. It is stated in the research conducted in Finland on the middle level executives working for the catering and food and drink businesses that intensive stress in the job environment feeling of occupational burnout might result in quitting the job (Dienstbühl et al., 2008; 64).

The intensive stress is experienced during the busy schedule hours especially at the hotels or food and drink businesses. The problems such as impatience of the customers, lack of personnel and the constraints about the business reflected to the personnel by the customers might be undergone. However, when we have a look at the other problems of the employees in travel and tourism industry the similar problems might be mentioned. It is possible to mention that they are gathered in the factors like lower wages, the extreme and irregular working hours and lack of occupational safety (Tatlıdil, 1998; 62). Nevertheless, Tanriverdi et al., (2001) stated that the personnel complain about intensive working hours, extreme work load, lower wages, not being promoted or not being awarded in consequence of the research conducted by him at the four or five-star-hotels operating in Turkey. Pavesic and Brymer (1990) mentioned that they quitted their job on account of long working hours, exhaustive works and lower wages regarding their studies performed on the young executives.

According to the European Foundation for the Improvement of Living and Working Conditions (2002), in comparison to the other sectors, the employees in the tourism sector are more exposed to the violence, harassment or discrimination stemming from their workmates or employers. Those who work for this sector, in comparison to the other sectors, face more with the intimidation (8.5\% in the food and beverage industry in response to $12 \%$ in the other sectors), physical violence (3.5\% in response to $6.5 \%$ ) and sexual 
implication (2\% in response to $8 \%$ ). Additionally, the personnel working in the food and drink industry suffer more from the discrimination $(6,5 \%$ in response to the $10,5 \%$ ) than the other employees (www.turizmdosyasi.com, 2009).

To sum up, the safety at the hotels is related with the prevention of the probable accidents. The aim is to protect the customers coming to the business and the employees from the possible accidents and dangers. The accidents generally result from not taking the necessary measures or lack of attention. The important point is that the executives plan in advance how to protect the customers or the employees from the accidents at the business. Another important point is to designate beforehand how to protect the business and equipments and how to minimize the probable losses and damages during the accident. What all the employees should do in the course of an accident or how they intervene in case a fire breaks out and who undertakes what should be fixed and the equipment must be formed for this (Denizer, 2005; 220).

\section{JOB SATISFACTION}

Job satisfaction means the contentment of the servers because of their jobs. Job satisfaction is the personal evaluation of the job conditions (the job itself, the attitude of the administration etc.) or the consequences or (wages, occupational security etc.) acquired from the job (Schneider ve Snyder, 1975; s.31). According to another definition Job satisfaction is the phenomenon ascertaining the contentment of the server and appearing when the qualifications of the job and the demands of the servers match (Akıncl, 2002; s.2). In line with these definitions Job satisfaction might be handled as the consequence resulting from the comparison between the expectations of the server from his job and the job in question which is performed. The consequence may emerge as satisfaction or dissatisfaction of the server from the job.

When the server sees that his expectations are not met in the job environment, the Job dissatisfaction emerges. It leads to the decrease in the workforce productivity, organizational commitment (Sagie, 1998; Payne ve Morrison, 2002; Redfern et al., 2002; Pekdemir et al., 2006) and commitment to the job and increase in the rates of the optional discontinuation of the job (Gellatly,1995; Sagie 1998). Besides, the medical conditions of the employees might be affected negatively. Lower job satisfaction in the servers has been observed to bring about neurotic (insomnia and headache) and emotional negativenesses (stress, disappointment) (Miner, 1992; 119).

Nevertheless, the best proof to the deterioration of the works is the lower job satisfaction. It causes secretly deceleration of the works, job success and job productivity and increases in the workforce turnover (Iverson ve Deery, 1997; Lum et al., 1998), occupational accidents and complaints. 
The job satisfaction is a topic to which the necessary importance should be attached in terms of its relation with discontinuation, personnel turnover and job success (Bingöl, 1998, s.268). The qualified personnel effect has a considerable amount of importance on attainment of the long-term-targets of especially the businesses operating in the tourism sector. Hence today's businesses consider the human resources as one of the invaluable fortunes of the organization (Akıncı, 2002; 4).

The employers' attitudes at the accommodation businesses are paid more attention than those of the other business lines. The level and utilization way of the attitudes such as personality, smiling face, courtesy, cordiality, philanthropy, respect, hygiene, benevolence and understanding are extremely important on the meeting the fundamental psychological needs of the customers. Due to the fact that hotel business is a sector in which the labour is highly intensive and the people are served by the people, the attitudes of the employees are complementary of the generation of the commodity and service in question as well as they are the determinants of the final quality, it is crucial and necessary for the attitudes to be measured (Kantarcl; 1997).

There are quite a few of problems arising from the job dissatisfaction and factors determinants of the dissatisfaction. The chief of these factors may be listed as (Oral, 1999;172-173):

$>$ The customer aggregates occurring at the reception

$>$ The unnecessary increase in the overwork wages in the business

$>$ The increase in the customer complaints

$>$ The increase in the server complaints

$>$ The growing losses in the consumption of the food and drink in the production sites

$>$ Emerging of the extreme troubles in the durable consumer goods

$>$ The increase in the fragilities of the restaurant goods

$>$ The increasing tendency towards the misuse of the equipment and materials

$>$ The increase in the occupational accidents

$>$ The quality deterioration of the food and beverage

$>$ Considerable failures and delays of the services

$>$ The decrease in the total sale and profit

$>$ The growing discontinuation of the server to the job

$>$ The increasing rate of the server turnover

The researches settled that job satisfaction or dissatisfaction, in other words, what the individual wants and what he has may be fixed well in line with a number of rating processes. The attitude scale is generally used for the job satisfaction measurements. One of the important scales accepted by the majority is Likert attitude scale. The questionnaires which are developed are generally concentrated on these scales (Tütüncü, 2000; 170). 


\section{AIM AND METHOD}

The aim of this study is to designate the risk factors encountered by the personnel working at the different departments and to associate it with their job satisfaction level in the scope of occupational health and safety. In this context, it is aimed to;

$>$ designate the physical, chemical, biological and psychological risk factors encountered by the hotel personnel

$>$ detect the job satisfaction level of the personnel

$>$ determine the relation between risk factors and their job satisfaction level

In this study, a literature review was done aiming to identify the occupational health and safety risk factors in addition to job satisfaction. Questionnaire survey was conducted to determine the levels of job satisfaction and opinions of the workers related to occupational health and safety risk factors in five-star hotel enterprises. The questionnaire consists of three parts: Scale totally with 25 closed-end statements about risk factors in part 1, consists of four constructs: Physical factors (7 items); chemical factors (6 items), psychological factors ( 7 items) and biological factors ( 5 items). The scale in part 1 was prepared by providing expert opinions and reviewing related literature. Part 2 covers 20 closed-end statements to identify the worker's level of job satisfaction. Job satisfaction was measured using the Minnesota Satisfaction Questionnaire (MSQ). Workers in hotel enterprises were asked to specify on a Likert scale which rating best described their view towards each statements reflecting occupational health and safety risk factors in addition to job satisfaction. Statements were framed in the format of a Likert Scale ranging from strongly disagrees to strongly agree. (1=strongly disagree $2=$ disagree, $3=$ neither agree nor disagree, $4=$ agree, $5=$ strongly agree). Part 3 is made of some variables used for measuring demographic characteristics of hotel workers included age, gender and education levels, marital status, monthly income, etc.

The population of the study comprises hotel employees working at 5-star hotel located in İstanbul province. In this frame, clustering sampling method has been used and 8 hotel enterprises have been treated as a cluster. The study population included 204 employees from eight five-star hotels in the İstanbul Region.

The individual features of the participants have been given with their frequency and percentage distribution in the process of the data analysis. However, the participants' opinions on occupational health and safety and job satisfaction have been described after they have been measured by the means and standard deviation. Whether there is a significant difference among the subdimensions (physical, chemical, socio-psychological and biological factors) has been tested through the one-way anova for the repeated measures. On the other hand, independent $t$ test and One-Way Anova have been implemented for 
the comparison of the participants' opinions about the situation by their individual features. The relation between the participants' opinions on occupational health and safety and job satisfaction level has been designated via correlation and multiple linear regression analysis $\left[Y_{i}=\beta_{0}+\beta_{1} X_{1}+\beta_{2} X_{2}+\right.$ $\ldots . .+\beta_{k} X_{k}+e$ ( $k=$ number of variables)]. Besides scale reliability analysis in this research has been fixed through the coefficient of Cronbach's Alpha.

\section{FINDINGS AND DISCUSSION}

Some findings of this research are shown in the tables below.

Table 1: The Distribution Concerning the Participants' Features $(n=204)$

\begin{tabular}{|c|c|c|c|c|c|c|c|}
\hline Var & GROUP & $\mathrm{F}$ & $\%$ & Var. & GROUP & $\mathbf{F}$ & $\%$ \\
\hline \multirow{3}{*}{ 蔍 } & Male & 134 & 65.7 & \multirow{6}{*}{ 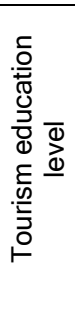 } & None & 58 & 28.4 \\
\hline & Female & 70 & 34.3 & & $\begin{array}{l}\text { Anatolia Hotel and Tourism } \\
\text { Vocational Lycée }\end{array}$ & 13 & 6.4 \\
\hline & Total & 204 & 100 & & Tourism two year degree & 24 & 11.8 \\
\hline \multirow{6}{*}{ 离 } & 20 and less & 15 & 7.4 & & $\begin{array}{l}\text { undergraduate and } \\
\text { post-graduate }\end{array}$ & 35 & 17.2 \\
\hline & $21-30$ & 93 & 45.6 & & Other (course and Certificate) & 35 & 17.2 \\
\hline & $31-40$ & 57 & 27.9 & & Total & 165 & 80.9 \\
\hline & $41-50$ & 20 & 9.8 & \multirow{5}{*}{ 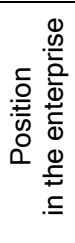 } & Higher-level manager & 8 & 3.9 \\
\hline & 51 and over & 19 & 9.3 & & Middle- level managers & 16 & 7.8 \\
\hline & Total & 204 & 100 & & Lower-level manager & 26 & 12.7 \\
\hline \multirow{4}{*}{ 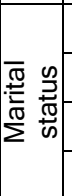 } & Married & 102 & 50.0 & & Other Personnel & 93 & 45.6 \\
\hline & Single & 74 & 35.8 & & Total & 143 & 70.1 \\
\hline & Widowed, or divorced & 23 & 11.7 & \multirow{6}{*}{ 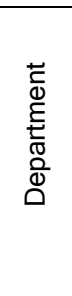 } & Front Office & 29 & 14.2 \\
\hline & Total & 199 & 97.5 & & Food and Beverage & 37 & 18.1 \\
\hline \multirow{6}{*}{ 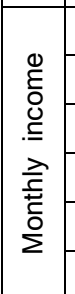 } & $750 \mathrm{TL}$ and less & 54 & 26.5 & & Housekeeping & 42 & 20.6 \\
\hline & 751TL-1000TL & 69 & 33.8 & & Technique service & 16 & 7.8 \\
\hline & 1001TL-1250TL & 40 & 19.6 & & Others & 40 & 19.6 \\
\hline & 1251TL-1500TL & 21 & 10.3 & & Total & 164 & 80.4 \\
\hline & 1501TL and over & 14 & 6.9 & \multirow{7}{*}{ 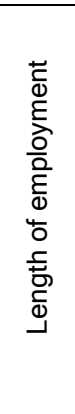 } & 5 year and less & 24 & 14.8 \\
\hline & Total & 198 & 97.1 & & $6-10$ year & 46 & 21.5 \\
\hline \multirow{5}{*}{ 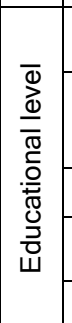 } & $\begin{array}{l}\text { Elementary- Junior } \\
\text { high school }\end{array}$ & 59 & 28.9 & & $11-15$ year & 30 & 14.7 \\
\hline & $\begin{array}{l}\text { vocational and } \\
\text { technical high schools } \\
\text { or lyceé }\end{array}$ & 59 & 28.9 & & 16- 20 year & 29 & 14.2 \\
\hline & Junior college degree & 26 & 12.7 & & 21 year and over & 55 & 27.0 \\
\hline & $\begin{array}{l}\text { Bachelor's degree } \\
\text { or post-graduate }\end{array}$ & 45 & 22.1 & & \multirow{2}{*}{ Total } & \multirow[t]{2}{*}{184} & \multirow[t]{2}{*}{90,2} \\
\hline & Total & 189 & 92.6 & & & & \\
\hline
\end{tabular}


According to the findings shown in table 1 , the majority of the participants comprises of the gentlemen (65.7\%), those between $21-30$ age groups (\%45.6), the married (50\%), and those who have a salary between 751-1000 TL. $12.7 \%$ of the participants is the higher-level manager and $45.6 \%$ of them is the other personnel. \%57.8 of them were graduated from vocational and technical high schools or lycee or has lower level of education. \%28.4 of the participants has stated that they didn't ever study tourism education.

Table 2: The Reliability and Factor Analysis Results of The Occupational Health and Safety Risk Factors Scale

\begin{tabular}{|l|r|r|r|}
\hline \multicolumn{1}{|c|}{ FACTORS } & $\begin{array}{c}\text { Cronbach } \\
\text { Alpha }\end{array}$ & \% of Variance & \% Cumulative \\
\hline Physical & .87 & 22.52 & 22.52 \\
\hline Chemical & .89 & 19.25 & 41.77 \\
\hline Socio-psychological & .80 & 18.35 & 60.12 \\
\hline Biological & .86 & 16.15 & 76.37 \\
\hline
\end{tabular}

According to the reliability analysis results shown in table 2 , it is seen that the Cronbach Alpha values are high. The Cronbach Alpha values have been calculated 0.87 for the physical factors, 0.89 for the chemical factors, 0.80 for the socio-psychological factors and 0.86 regarding the biological factors. The coefficient of the Cronbach Alpha has been calculated 0.82 for the job satisfaction scale. According to the results of the factor analysis aforesaid four factors explain the $\% 76.37$ of the total variance.

Table 3 shows that there is a significant relation among the occupational health and safety factors and the aforesaid sub-dimensions $(p<0.001)$. When the averages regarding the dimensions it is seen that the most positive opinions of the participants are about the physical factors of the hotel enterprises $(\bar{X}=3.97)$ while the most negative ones are about the socio-psychological factors $(\bar{X}=3.26)$. Although the participants have more positive opinions about the hotel's ground being always clean and dry or seeing the necessary measures about cutters, drillers and hurtful having been taken before, they show a critical approach about the adequacy of the wages and not having a fair promotion system in comparison to the other points.

It can be seen from Table 4 that the job satisfaction of the participants is higher than the middle level. The participants especially stated that they find their jobs more satisfactory because it makes them feel they have completed their duty successfully and they get along well with each other. On the contrary, they have delivered negative opinions about the wages, enterprise policies and their implementations and the promotion possibility in comparison to the other points. 
Tablo 3: Descriptive Statistics Concerning The Occupational Health and Security Risk Factors and The Comparison of The Factors.

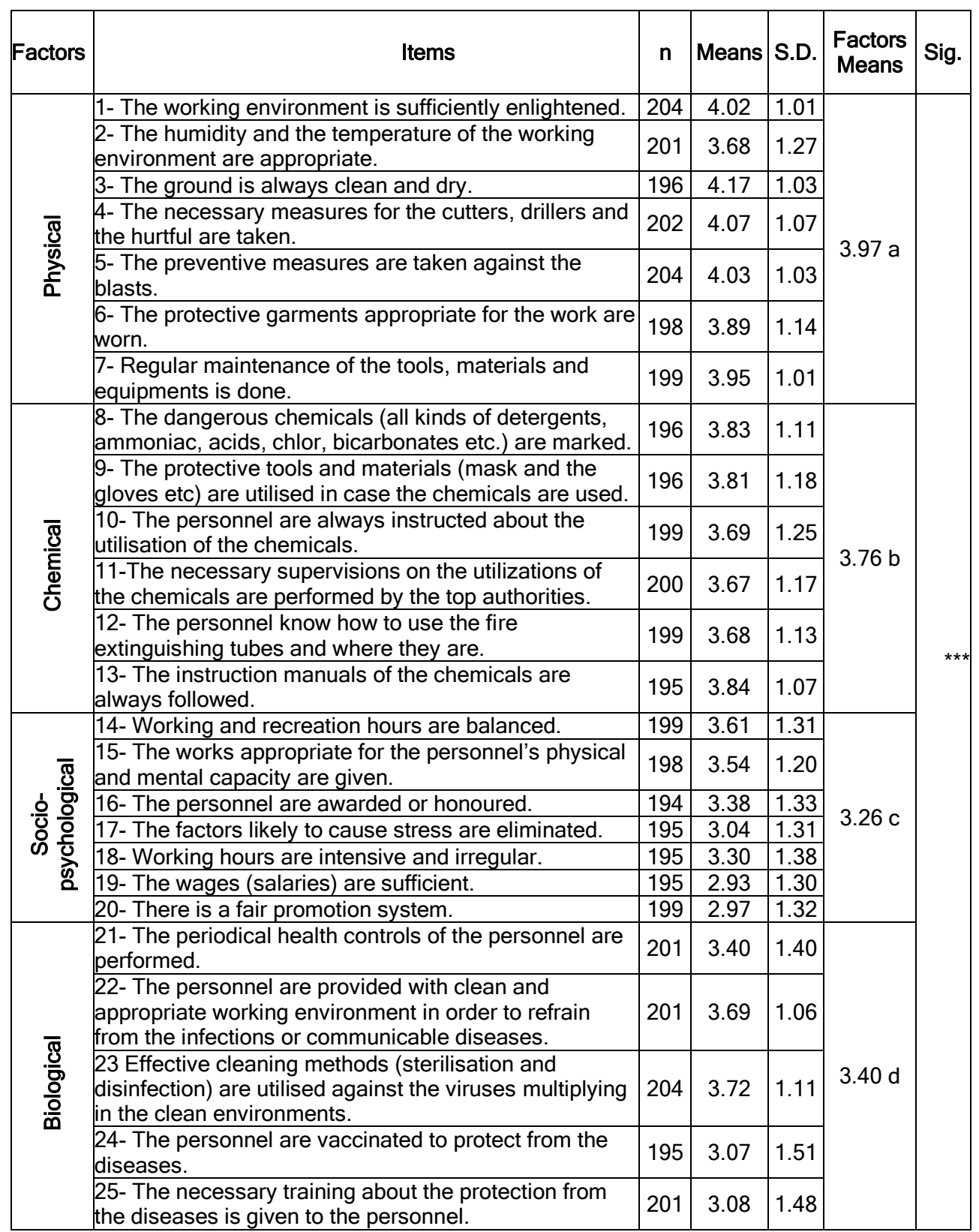

${ }^{* * *}: \mathrm{p}<0.001 \mathrm{a}, \mathrm{b}, \mathrm{c}, \mathrm{d}$ : There is a significant difference among the factors comprising the different letters. 
Table 4: Descriptive Statistics Related to Job Satisfaction

\begin{tabular}{|l|r|r|r|}
\hline On my present job, this is how I feel about.... & N & Mean & S.D. \\
\hline 1- Being able to keep busy all the time & 200 & 3.51 & 1.16 \\
\hline 2- The feeling of accomplishment I get from the job & 200 & 3.88 & .92 \\
\hline 3- Being able to do things that don't go against my conscience & 197 & 3.49 & 1.21 \\
\hline 4- The freedom to use my own judgment & 203 & 3.34 & 1.11 \\
\hline 5- The way my job provides for steady employment & 200 & 3.50 & 1.20 \\
\hline 6- The chance to tell others what to do & 200 & 3.54 & 1.11 \\
\hline 7- The chance to work by myself & 201 & 3.47 & 1.19 \\
\hline 8- The chance to do something that makes use of my abilities & 196 & 3.49 & 1.02 \\
\hline 9- The chance to make use of my abilities and skills & 199 & 3.59 & 1.08 \\
\hline 10- The chance to do things for other people & 198 & 3.46 & 1.09 \\
\hline 11- The chance to be "somebody" in the community & 192 & 3.57 & 1.21 \\
\hline 12- The chance to do different things from time to time & 193 & 3.43 & 1.33 \\
\hline 13- The way promotions are given out on this job & 201 & 3.30 & 1.39 \\
\hline 14- The way company policies are put into practice & 199 & 3.23 & 1.27 \\
\hline 15- My pay and the amount of work I do & 198 & 3.18 & 1.32 \\
\hline 16- The way I am noticed when I do a good job & 196 & 3.40 & 1.27 \\
\hline 17- The competence of my supervisor in making decision & 195 & 3.51 & 1.30 \\
\hline 18- The way my boss handles his/her employees & 194 & 3.44 & 1.28 \\
\hline 19- The working conditions (heating, lighting ventilation, etc) & 201 & 3.59 & 1.28 \\
\hline 20- The chance to develop close-friendships with my co-workers. & 198 & 3.65 & 1.23 \\
\hline
\end{tabular}

According to the findings shown in table 5 , the significant relations have been fixed among some of their features (except the marital status and the working time period in the enterprise) and some variables (such as physical, chemical, socio-psychological, biological factors and job satisfaction) about which they have delivered their opinions $(p<0.05)$. When the averages are examined it is seen that the job satisfaction of the gentlemen $(\bar{X}=3.61)$ is higher than that of the ladies $(\bar{x}=3.22)$. However, those who are 20 years old and less, those who have salaries of $750 \mathrm{TL}$ or less and those who have primary or high school education delivered more negative opinions than the other groups about the sub-dimensions concerning the occupational health and safety risk factors. Those who have tourism licenses or those who have upper education level, those who are not executives in the enterprise and the ones working in the department of housekeeping delivered more negative opinions about the chemical factors then the other groups. Those who have tourism education through the courses and certificate programs and the ones who are not executives stated more negative approaches on the job satisfaction, biological and socio-psychological factors and those who work for the housekeeping and food and beverage department showed more negative approaches about the job satisfaction and socio-psychological factors when compared to the other groups. 
Table 5: Comparison by Respondent Characteristics of Occupational Health and Safety Risk Factors and Job Satisfaction Means

\begin{tabular}{|c|c|c|c|c|c|c|c|c|c|c|c|}
\hline \multirow{3}{*}{ Var. } & \multirow{3}{*}{ Group } & \multicolumn{8}{|c|}{ Occupational health and safety risk factors } & & \\
\hline & & \multicolumn{2}{|c|}{ Physical } & \multicolumn{2}{|c|}{ Chemical } & \multicolumn{2}{|c|}{$\begin{array}{c}\text { Socio- } \\
\text { Psychological }\end{array}$} & \multicolumn{2}{|c|}{ Biological } & \multicolumn{2}{|c|}{$\begin{array}{c}\text { Job } \\
\text { satisfaction }\end{array}$} \\
\hline & & mean & s.d. & mean & s.d. & mean & s.d. & mean & s.d. & mean & s.d. \\
\hline \multirow{3}{*}{ œ } & Male & 4.00 & .71 & 3.80 & .82 & 3.25 & .73 & 3.43 & 1.05 & 3.61 & .77 \\
\hline & Female & 3.88 & .91 & 3.65 & 1.06 & 3.28 & .97 & 3.34 & 1.02 & 3.22 & .81 \\
\hline & Sig. & \multicolumn{2}{|l|}{-} & \multicolumn{2}{|l|}{-} & \multicolumn{2}{|l|}{-} & \multicolumn{2}{|l|}{-} & \multicolumn{2}{|c|}{ 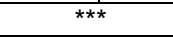 } \\
\hline \multirow{6}{*}{ 完 } & 20 and less & $3.28 a$ & 1.28 & $3.06 a$ & 1.21 & $2.89 a$ & 1.28 & $2.76 a$ & 1.26 & $2.99 a$ & .75 \\
\hline & $21-30$ & $4.03 b$ & .72 & $3.63 b$ & 1.00 & $3.12 b$ & .86 & $3.18 b$ & 1.03 & $3.31 b$ & .80 \\
\hline & $31-40$ & $3.99 b$ & .73 & $3.65 b$ & .70 & $3.44 \mathrm{c}$ & .77 & $3.89 c$ & .95 & $3.79 c$ & .82 \\
\hline & $41-50$ & $4.08 \mathrm{~b}$ & .71 & $4.24 c$ & .55 & $3.62 d$ & .47 & $3.47 \mathrm{~d}$ & .88 & $3.80 c$ & .41 \\
\hline & 51 and over & $4.09 \mathrm{~b}$ & .66 & $3.75 b$ & .55 & $3.19 \mathrm{~b}$ & .74 & $3.43 d$ & .78 & $3.37 b$ & .74 \\
\hline & Sig. & \multicolumn{2}{|c|}{ *** } & \multicolumn{2}{|c|}{$* * *$} & \multicolumn{2}{|c|}{$* * *$} & \multicolumn{2}{|c|}{$* * *$} & \multicolumn{2}{|c|}{$* * *$} \\
\hline \multirow{6}{*}{ 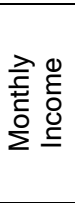 } & 750 TL and less & $3.66 a$ & .91 & $3.30 \mathrm{a}$ & 1.01 & $2.86 a$ & .92 & $2.88 a$ & .98 & $3.12 a$ & .83 \\
\hline & 751TL-1000TL & $4.09 \mathrm{~b}$ & .73 & $3.82 \mathrm{~b}$ & .86 & $3.36 b$ & .74 & $3.51 b$ & 1.13 & $3.57 \mathrm{~b}$ & .83 \\
\hline & 1001TL-1250TL & $3.94 b$ & .67 & $3.95 b$ & .66 & $3.32 b$ & .79 & $3.69 b$ & .81 & $3.47 b$ & .77 \\
\hline & 1251TL-1500TL & $4.02 b$ & .65 & $3.90 \mathrm{~b}$ & .77 & $3.50 \mathrm{c}$ & .94 & $4.11 \mathrm{c}$ & .64 & $3.75 c$ & .52 \\
\hline & 1501TL and over & $4.06 \mathrm{~b}$ & .65 & $4.28 \mathrm{c}$ & .87 & $3.46 \mathrm{c}$ & .62 & $3.37 d$ & 1.04 & $3.87 \mathrm{c}$ & .65 \\
\hline & Sig. & \multicolumn{2}{|c|}{$\star * *$} & \multicolumn{2}{|c|}{ ** } & ** & & ** & & ** & \\
\hline & $\begin{array}{l}\text { Elementary- Junior } \\
\text { high school }\end{array}$ & $3.75 a$ & .93 & $3.70 \mathrm{a}$ & .93 & $2.98 a$ & .85 & $3.29 a$ & 1.08 & $3.32 a$ & .85 \\
\hline 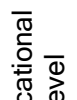 & $\begin{array}{l}\text { vocational and } \\
\text { technical high schools } \\
\text { or lyceé }\end{array}$ & $4.01 \mathrm{~b}$ & .71 & $3.62 a$ & .98 & $3.39 b$ & .67 & $3.59 b$ & .98 & $3.44 b$ & .72 \\
\hline$\frac{0}{\partial} \underline{0}$ & Junior college degree & $4.18 \mathrm{~b}$ & .58 & $3.71 a$ & .68 & $3.29 \mathrm{~b}$ & .76 & $3.49 b$ & .90 & $3.63 c$ & .64 \\
\hline & $\begin{array}{l}\text { Bachelor's degree } \\
\text { or post-graduate }\end{array}$ & $4.14 b$ & .71 & $4.16 b$ & .80 & $3.43 b$ & .91 & $3.68 b$ & 1.03 & $3.67 c$ & .87 \\
\hline & Sig. & ** & & ** & & ** & & * & & ** & \\
\hline & None & 3.96 & .75 & $3.80 \mathrm{a}$ & .82 & $3.37 a$ & .60 & $3.53 a$ & .89 & $3.26 a$ & .67 \\
\hline & $\begin{array}{l}\text { Anatolian Tourism and } \\
\text { Hotel Vocational High } \\
\text { School }\end{array}$ & 3.57 & .48 & $3.84 a$ & .46 & $3.65 b$ & .74 & $3.89 b$ & .81 & $4.01 \mathrm{~b}$ & .73 \\
\hline ঠ & $\begin{array}{l}\text { Tourism two year } \\
\text { degree }\end{array}$ & 4.08 & .56 & $3.67 a$ & .65 & $3.26 \mathrm{c}$ & .630 & $2.97 \mathrm{c}$ & .91 & 3.61a & .77 \\
\hline $\begin{array}{l}\dot{\Psi} \underline{\underline{E}} \\
\varepsilon\end{array}$ & $\begin{array}{l}\text { undergraduate and } \\
\text { post-graduate }\end{array}$ & 4.17 & .77 & $4.17 b$ & 69 & $3.65 b$ & .16 & $4.00 \mathrm{~b}$ & .74 & $3.91 \mathrm{c}$ & .59 \\
\hline$\frac{\bar{n}}{\overline{\frac{n}{7}}}$ & $\begin{array}{l}\text { Other(course and } \\
\text { Certificate pogram) }\end{array}$ & 4.06 & .78 & $3.46 c$ & 1.29 & $2.90 \mathrm{~d}$ & .92 & $2.78 \mathrm{c}$ & 1.15 & $3.18 a$ & 1.02 \\
\hline & Sig. & - & & * & & * & & * & & ** & \\
\hline & Higher-level manager & 3.83 & .54 & $3.91 a$ & .66 & $3.82 a$ & .73 & $3.82 a$ & .68 & $3.98 a$ & .64 \\
\hline & Middle-level managers & 4.26 & .76 & $4.61 \mathrm{~b}$ & .47 & $4.08 a$ & .39 & $4.12 a$ & .73 & $4.09 a$ & .29 \\
\hline 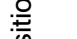 & Lower-level manager & 4.07 & .64 & $4.01 a$ & .69 & $3.55 b$ & .59 & $3.69 b$ & .92 & $3.70 b$ & .61 \\
\hline రి & Other Personnel & 3.87 & .89 & $3.60 \mathrm{c}$ & .94 & $3.12 \mathrm{c}$ & .92 & $3.17 \mathrm{c}$ & 1.08 & $3.38 \mathrm{c}$ & .80 \\
\hline & Sig. & - & & ** & & ** & & ** & & ** & \\
\hline & Front Office & 4.05 & .83 & $3.74 a$ & .93 & $3.26 \mathrm{a}$ & .96 & 3.44 & .98 & $3.64 a$ & .86 \\
\hline$\frac{\tilde{Q}}{\varrho}$ & Food and Beverage & 3.95 & .53 & $3.80 a$ & .73 & $3.09 b$ & .74 & 3.49 & 1.04 & $3.39 b$ & .73 \\
\hline$\underline{E}$ & Housekeeping & 3.96 & .71 & $3.51 \mathrm{~b}$ & .97 & $3.14 \mathrm{~b}$ & .69 & 3.24 & .91 & $3.28 b$ & .85 \\
\hline$\frac{\pi}{\pi}$ & Technique service & 4.12 & .87 & $3.86 a$ & .95 & $3.30 a$ & .40 & 3.41 & 1.01 & $3.71 a$ & .96 \\
\hline ๑ั & Others & 4.25 & .64 & $4.10 \mathrm{c}$ & .72 & $3.62 \mathrm{c}$ & .87 & 3.70 & .94 & $3.93 c$ & .53 \\
\hline & Sig. & - & & & & * & & - & & $+x$ & \\
\hline
\end{tabular}


*: $p<0.05 \quad * *: p<0.01 \quad{ }^{* * *}: p<0.001 \quad a, b, c, d:$ There is a significant difference among the factors comprising the different letters.

According to the variance analysis results shown in table 6 , the multiple linear regression model belonging to the relation among the dependent variables (job satisfaction level) and the independent variables (physical, chemical, sociopsychological and biological factors) has been found significant ( $F=58.298$; $p<0,001)$. Accordingly, the coefficients found for the multiple linear regression model is significant and it does not equal to zero.

Table 6: Variance Analysis for Multiple Linear Regression Model

\begin{tabular}{|c|c|c|c|c|c|}
\hline & Sum of Squares & df & Mean Square & $F$ & Sig. \\
\hline Regression & 71.473 & 4 & 17.868 & \multirow[t]{3}{*}{58.298} & \multirow{3}{*}{$* * *$} \\
\hline Residual & 60.686 & 198 & .306 & & \\
\hline Total & 132.158 & 202 & & & \\
\hline
\end{tabular}

When the table 7 on which the multiple linear regression coefficients and importance controls are written is analysed, it is seen that the physical, chemical, socio-psychological and biological factors have a considerable effect on the job satisfaction $(p<0,001)$. $T$ values on the table 7 show that the most important factors on the job satisfaction are the biological and chemical risk factors. This finding parallels with the correlation coefficients among the variables. The correlation coefficients point to the high relation level among the job satisfaction, biological $(r=0.664)$ and chemical $(r=0.622)$ risk factors while they show a middle relation level among the job satisfaction, physical $(r=0.461)$ and socio-psychological $(r=0.435)$ risk factors.

Table 7: Findings Related to Multiple Linear Regression Model

\begin{tabular}{|c|c|c|c|c|c|c|c|}
\hline $\begin{array}{c}\text { Dependent } \\
\text { variables }\end{array}$ & $\begin{array}{c}\text { Coefficients } \\
\beta_{i}\end{array}$ & $\begin{array}{l}\text { Std. } \\
\text { Err. }\end{array}$ & Beta & $t$ & Sig. & \multicolumn{2}{|c|}{$\begin{array}{c}\text { Pearson } \\
\text { Correlation }\end{array}$} \\
\hline (Constant) & .772 & .213 & & 3.617 & $* * *$ & $r$ & Sig. \\
\hline Physical & .112 & 063 & .109 & 1.785 & * & .461 & $* * *$ \\
\hline Chemical & 252 & 060 & .282 & 4.199 & $\star * \star$ & 622 & *** \\
\hline Socio-psychological & .090 & .063 & .070 & 1.054 & * & .435 & $\star \star * *$ \\
\hline Biological & .323 & .051 & .418 & 6.343 & *** & 664 & $* * *$ \\
\hline
\end{tabular}

The explanatory character of the model has been calculated $\% 54.1\left(R^{2}=54.1\right)$ and the multiple linear regression model in consequence of the analysis may be stated as below: Multiple linear regression model: Job satisfaction $=0.772+$ Physical ${ }^{*} 0.112+$ Chemical ${ }^{*} 0.252+$ Socio-psychological ${ }^{*} 0.090+$ Biological ${ }^{*} 0.323$ 


\section{CONCLUSIONS AND RECOMMENDATIONS}

According to the results of the analysis stated above, it is seen that job satisfaction of the gentlemen is higher than that of the ladies. those who are 20 years old and less, those who have salaries of 750 TL or less and those who have primary or high school education delivered more negative opinions than the other groups about the sub-dimensions concerning the occupational health and safety risk factors. Those who have tourism licenses or those who have upper education level, those who are not executives in the enterprise and the ones working in the department of housekeeping delivered more negative opinions about the chemical factors then the other groups. Those who have tourism education through the courses and certificate programs and the ones who are not executives stated more negative approaches on the job satisfaction, biological and socio-psychological factors and those who work for the housekeeping and food and beverage department showed more negative approaches about the job satisfaction and socio-psychological factors when compared to the other groups.

The results indicate that the physical, chemical, socio-psychological and biological factors have a considerable effect on the job satisfaction. The most important factors on the job satisfaction are the biological and chemical risk factors. it is expected that as long as the risk level on the occupational health and security increase the satisfaction level of the employees will accordingly decrease.

In addition to these results, we can produce some solution and recommendations in the light of the knowledges based on literature in this research:

Those who utilize some kinds of machines must be trained and the dangers should be mentioned. The garments of the people utilizing some machines must not droop; the sleeves should be short and from the rubber; the bonnet should be worn to avoid from the contact with the machines and the jewelers should be taken out. Additionally dish washers who clean these sharp tools cut themselves easily when they do not wear plastic gloves (Koçak, 2006; 133; www.isguvenligi.net, 2009).

Deep freezers as large as a room might be used for doing food services to the customers and keeping some of the convenience foods, sauces, fruits, vegetables, fish and the meat in proper conditions in that sort of businesses. The necessary measures for the risk of the closing of the door should be taken after entering into the cold warehouses. Therefore the doors of the deep freezers can be opened inside or the alarm system should be installed inside.

After the dangerous sources have been designated by the enterprise with a view to shaping the studies of the occupational health it should be regularly supervised and examined. In consequence of the researches the inadequacies 
of the system must be fixed and the accidents can be foreseen and necessary measures might be taken (Kozak, 2006; 168). Nevertheless, all the employees should be trained against accident possibility. In case an accident occurs in the enterprise the administration should take the necessary measures to avoid another accident (Koçak, 2006; 132).

Various measures should be taken in order to avoid the employees from being negatively affected and to minimize the socio-psychological risks stemming from the hotel enterprises' performing in a sector in which the labour is highly intensive by the administration. This might be listed as assigning the personnel with the duties appropriate for his physical and mental capacity, stabilizing the working and resting hours, elimination of the concern for the safeguarding of the job, awarding the employees, to ensure a sound communication between personnel and administration and backing up the personnel regarding the settlement of their familial and individual problems (Seymen ve Gül, 2004; 202).

The following measures might be listed in order to minimize the risks stemming from the biological factors and likely to be encountered by the personnel in the hotel enterprises. These are attaching importance to the sterilization and disinfection, making sure that the personnel is vaccinated, being stick to the hygiene and sanitation rules and providing the personnel with necessary training (Denizer, 2005; 227; Seymen ve Gül, 2004; 202).

What should be done by the principals and high administration of the housekeeping department in order to minimize the risks stemming from the chemicals might be summarized as: favouring the least dangerous chemicals, training the personnel regarding the related topic, ensuring that the personnel stick to the instruction manual, making sure that the personnel utilize the protective tools and materials, performing periodical measurements of the environments in which the chemicals are used and having the employees undergo the periodical physical examinations.

\section{REFERENCES}

AKINCI, Z. (2002): "Turizm Sektöründe İşgören İş Tatminini Etkileyen Faktörler: Beş Yıldızlı Konaklama İşletmelerinde Bir Uygulama", Akdeniz Üniversitesi İktisadi ve İdari Bilimler Fakültesi Dergisi, 4: 1-25.

BINGOL, D. (1998): İnsan Kaynakları Yönetimi, Dördüncü Bası, İstanbul, Beta Basım Yayım Dağıım A.Ş.

BOLAT, T., SEYMEN, A.O., and BOLAT O. İ,. (2001): Termal Turizm İşletmelerinde İşgören Sağlığı ve İş Güvenliği Sorunları ve Çözüm Yolları: Bir Uygulama, Birinci Ulusal Kaplıca Turizmi Sempozyumu, Balıkesir Üniversitesi Gönen Meslek Yüksekokulu, 5-6 Mayıs 2001: 1-35. 
DAVIS, K. (1988): İşletmede İnsan Davranışı-Örgütsel Davranış, Çev: Kemal Tosun, İstanbul, İstanbul Üniversitesi İşletme Fakültesi Yayını.

DENIZER, D. (2005): Konaklama İşletmelerinde Yiyecek ve İçecek Yönetimi, Ankara, Detay Yayıncilık.

DIENSTBUHL, I., MICHAELIS, R., SCHARMENTKE, M., BUFFET , M., ROSKAMS, N., VAN HERPE, S., KARJALAINEN, K., KOUKOULAKI, T., GERVAIS, R., STABILE, S., KARANIKA, M., KOUVONEN, A., NAROCKI, C. and LISSNER L,. (2008): Protecting Workers in Hotels, Restaurants and Catering. European Agency for Safety and Health at Work. http://osha.europa.eu/en/publications/reports/TE7007132ENC_horeca (Erişim Tarihi: 14.02.2009).

EUROSTAT, (2003): "European Social Statistics,-Accidents at Work and Workrelated Health Problems", Work-related health problems by sex, diagnosis group, activity status, age and severity 1999, http://epp.eurostat.ec.europa.eu/portal/page, (Erişim Tarihi: 25.11.2007).

EUROSTAT, (2007): Europe in Figures-Eurostat Yearbook 2006-07, Eurostat Statistical Books, Luxembourg: Office for Official Publications of the European Communities.

FLETCHER, C. and WILLIAMS, R. (1996): "Performans Management, Job Satisfaction and Organizational Commitment", British Journal of Management, 7(2): 169-179.

GELLATLY, I. R. (1995): "Individual and Group Determinants of Employee Absenteeism: A Test of A Causal Model", Journal of Organizational Behavior, 16: 469-485.

IVERSON, R. D. and DEERY, M. (1997): “ Turnover Culture in The Hospitality Industry", Human Resource Management Journal, 7 (4): 71-82.

KANTARCI, K. (2004): Konaklama İşletmelerinde Önbüro İşlemleri ve Yönetimi. Ankara, Detay Yayıncilık.

KANTARCI, K. (1997): Otel İşletmelerinde İş Tatminin Ölçülmesi ve İşgören Performansına Etkileri, Basılmamış Doktora Tezi, İzmir, Dokuz Eylül Üniversitesi Sosyal Bilimler Enstitüsü.

KOÇAK, N. (2006): Yiyecek İçecek Hizmetleri Yönetimi, Gözden Geçirilmiş 3. Baskı, Ankara, Detay Yayıncılık,

KOZAK, AKOGLAN, M. (2006): Otel İşletmelerinde Kat Hizmetleri Yönetimi, Genişletilmiş 5. Baskı, Detay Yayıncılık, Ankara.

LIOU, K.T. (1995): "Understanding Employee Commitment in The Public Organization: A Study of the Juvenile Detention Center", International Journal of Public Administration, 18(8): 1269- 1295. 
LUM, L., KERVIN, J., CLARK, K., REID, F., and SIROLA W,. (1998): "Explaining Nursing Turnover Intent: Job Satisfaction, Pay Satisfaction, or Organizational Commitment?", Journal of Organizational Behavior, 19: 305-320.

MINER, J.B. (1992): Industrial- Organizational Psychology, McGraw-Hill Int, Singapore.

ORAL, S. (1999): Otel İşletmeciliği ve Otel İşletmelerinde Verimlilik Analizleri, Kanyılmaz Matbaası, İzmir.

ÖNCÜ, H. (2008): Otel ve Restoran İşletmeleri için İş Sağllığı ve Güvenliğine

Dair lyi Uygulama Örnekleri $A B$ Raporunda Sunuluyor. http://www.turizmdosyasi.com/haber_oku.asp?haber=1077\# (Erişim tarihi: 15 Kasım 2008).

PAYNE, R. L. and MORRISON, D. (2002): "The Differential Effects of Negative Affectivity on Measures of Well- Being Versus Job Satisfaction and Organizational Commitment", Anxiety, Stress and Coping, 15 (3): 231-244.

PEKDEMIR, I., ÖZCELIK, O., KARABULUT, E., and ARSLANTAS C.C.. (2006): "Personel Güçlendirme, İş Tatmini ve Örgütsel Bağlıık Arasındaki ilişskileri Belirlemeye Yönelik Bir Araştırma”, Verimlilik Dergisi, 4: 11-36.

REDFERN, S., HANNAN, S., NORMAN, I., and MARTIN, F,. (2002): "Work Satisfaction, Stress, Quality of Care and Morale of Older People in a Nursing Home", Health and Social Care in The Community, 10 (6): 512- 517.

REICHERS, A. E. (1985): "A Review and Reconceptualization of Organizational Commitment", Academy of Management Review, 10 (3): 465-476.

SAGIE, A. (1998): "Employee Absenteeism, Organizational Commitment and Job Satisfaction: Another Look", Journal of Vocational Behavior, 52: 156-171

SCHNEIDER, B. and SNYDER, R. (1975): " Some Relationships Between Job Satisfaction and Organizational Climate", Journal of Applied Psychology, 60 (3): 318-328.

SOSYAL GUVENLIK KURUMU (SGK). (2007): 'İ̧̧ Kazası ve Meslek Hastalıkları İstatistikleri', İstatistik Yıllığı.

SEYMEN, A.O. and GÜL, K.M. (2004): Konaklama İşletmelerinde Çağdaş Kat Hizmetleri Yönetimi, Gözden Geçirilmiş ve Genişletilmiş 2. Baskı, .Ankara, Detay Yayınclık.

UYAN, M.K. (2008), Yiyecek Endüstrisinde İşçi Sağlığı ve İş Güvenliği, www. isguvenligi.net/index.php?option=com_content\&task=view\&id=948\&ltemid =52, (Erişim Tarihi: 20.02.2009).

TÜTÜNCÜ, Ö. (2000): "Kâr Amacı Gütmeyen Yiyecek-i̇çecek İşletmelerinde İş Doyumunun Analizi”, Dokuz Eylül Üniversitesi Sosyal Bilimler Enstitüsü Dergisi, 2 (3): 169-171. 
YILMAZ, F. (2009): "Küreselleşme Sürecinde Gelişmekte Olan Ülkelerde ve Türkiye'de İş Sağlığı ve Güvenliği”, Uluslararası İnsan Bilimleri Dergisi, 6(1): 4572.

http://www.isguvenligi.net/index.php?option=com_content\&task=view\&id=942\&l temid=52, (Erişim tarihi: 12.02.2009).

http://www.turizmdosyasi.com/haber_oku.asp?haber=1077\#, (Erişimtarihi: 15.02.2009). 